\title{
ANISOTROPY OF MAGNETIC SUSCEPTIBILITY (AMS) IN VOLCANIC FORMATIONS: THEORY AND PRELIMINARY RESULTS FROM RECENT VOLCANICS OF BROADER AEGEAN.
}

\author{
Zananiri I. and Kondopoulou D. \\ Department of Geophysics, School of Geology, Aristotle University of Thessaloniki, P.O. Box \\ 352-1, 54124,.Thessaloniki, izanan@lemnos.geo.auth.gr, despi@geo.auth.gr
}

\begin{abstract}
The anisotropy of magnetic susceptibility (AMS) is a physical property of rocks widely used in petrofabric studies and other applications. It is based on the measurement of low-field magnetic susceptibility in different directions along a sample. From this process several scalar properties arise, defining the magnitude and symmetry of the AMS ellipsoid, along with the magnetic foliation, namely the magnetic fabric. Imaging the sense of magma flow in dykes is an important task for volcanology; the magnetic fabric provides a fast and accurate way to infer this flow direction. Moreover, the AMS technique can be used in order to distinguish sills and dykes, a task that is almost impossible by using only field observations. Finally in the case of lava flows, the method can be applied to define the local flow conditions and to indicate the position of the "paleo" source region. However, this technique is quite new in Greece. Some preliminary results from volcanic formations of continental Greece and Southern Aegean are presented (Aegina, Almopia, Elatia, Gavra, Kos, Patmos, Samos, Samothraki and Santorini).
\end{abstract}

\section{KEYWORDS}

Anisotropy of magnetic susceptibility (AMS), volcanology, petrofabrics, flow directions, Greek volcanics.

\section{INTRODUCTION}

The anisotropy of magnetic susceptibility (AMS) is a physical property of rocks widely used in petrofabric studies and other applications. This technique, combined with palaeomagnetism and rock magnetism can greatly contribute to volcanology by providing: (1) a correlation or dating tool; (2) a way of documenting the tilting and rotation of rocks; (3) a way of assessing the thermal history of rocks; and (4) a magma flow direction indicator (e.g. Ernst 1990, McKenzie et al. 1992, Tarling \& Hrouda 1993, Raposo \& D'Agrella-Filho 2000, and references therein).

Petrofabric studies in volcanic rocks are difficult due to fine grain size and weak preferred orientation. The AMS efficiency in determining the internal structures, t.i. the flow plane and/or direction, of these rocks has been demonstrated in volcanic formations throughout the world (e.g. Dragoni et al. 1997, Le Pennec et al. 1998, Smith 1998, Varga et al. 1998, Archanjo et al. 2000, Canon-Tapia \& Pinkerton 2000 among others). The method favours great acceptance because: it exhibits high sensitivity, is non time-consuming and can be applied to a variety of formations - lava flows, pyroclastic deposits, ash and tuff flows, ignimbrites, sills and dykes. 


\section{METHODOLOGY}

\subsection{Sampling and measurement of AMS}

Oriented drilled cores or hand samples are collected on the basis of access, freshness of material and presence of flow structures. The number and distribution of sites are determined by the nature of the studied formation, e.g. different sampling strategy for dykes and lava flows.

The magnetic susceptibility, $k$, represents the response of a body when it is inserted in a magnetic field, and is an intrinsic physical property of minerals. In rock samples and minerals, $k$, varies with the direction of measurement, and can be regarded at a first approximation, in low-field and low temperature, as a symmetrical, second rank tensor. Thus, it is geometrically represented by a triaxial ellipsoid of $K_{1} \geq K_{2} \geq K_{3}$ major axes.

Laboratory measurement of the magnetic susceptibility is performed either by the Agico Kappabridge KLY-2/3/4 susceptibility bridges, or the Sapphire apparatus. Each anisotropy of magnetic susceptibility (AMS) measurement yields the magnitudes of the three principal orthogonal axes of the AMS ellipsoid, and their declinations and inclinations with respect to the geographical frame. The bulk magnetic susceptibility magnitude is given by eq. 1 . The anisotropy degree (eq. 2), and the shape parameter (eq. 2) of Jelinek (1981) are the most commonly used scalar AMS parameters.

$$
\mathrm{K}_{\mathrm{m}}=\left(\mathrm{K}_{1}+\mathrm{K}_{2}+\mathrm{K}_{3}\right) / 3
$$

$$
\mathrm{P}^{\prime}=\exp \sqrt{\left[\left(\ln \frac{\mathrm{K}_{1}}{\mathrm{~K}_{\mathrm{m}}}\right)^{2}+\left(\ln \frac{\mathrm{K}_{2}}{\mathrm{~K}_{\mathrm{m}}}\right)^{2}+\left(\ln \frac{\mathrm{K}_{3}}{\mathrm{~K}_{\mathrm{m}}}\right)^{2}\right]}
$$

$$
\mathrm{T}=(\ln \mathrm{F}-\ln \mathrm{L}) /(\ln \mathrm{F}+\ln \mathrm{L})
$$

where

$$
\mathrm{F}=\mathrm{K}_{2} / \mathrm{K}_{3} \& \mathrm{~L}=\frac{\mathrm{K}_{1}}{\mathrm{~K}_{2}}
$$

\subsection{General character of AMS in volcanics}

The magnetic anisotropy of volcanic rocks is derived from the viscous flow during their emplacement. Various studies (Khan 1962, Bolshakov \& Skorodkin 1967, Le Pennec et al. 1998, Zanella et al. 1999, among others) showed that the degree of magnetic anisotropy in volcanic rocks is usually low, less than $10 \%$, while the bulk susceptibility ranges according to the magnetic mineralogy, but most commonly is of the order of $10^{-3}-10^{-2} \mathrm{SI}$. The low anisotropy suggests that the orientation mechanism of ferromagnetic minerals is not very effective.

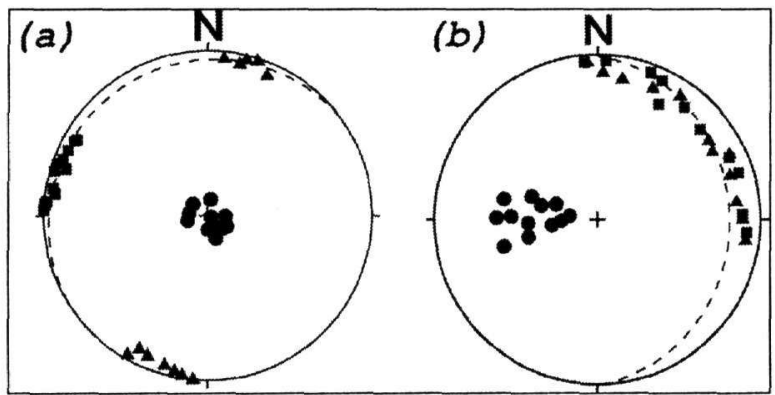

Figure 1. Representative magnetic fabrics of volcanic formations. Squares represent $K_{1}$ axes, triangles $K_{2}$ axes, circles $\mathrm{K}_{3}$ axes, and dashed line represents the foliation plane.

Lava flows, dykes and sills have fabrics that tend to be more foliated than lineated, and since the foliation plane lies close to the flow plane, their minimum susceptibility axes are perpendicular to it. The predominance of foliation means that the maximum and intermediate axes commonly form a girdle on the stereographic projection (Fig. 1a), or can be sometimes grouped either parallel or 
perpendicular to the flow direction (Fig. 1b) (Khan 1962, Ellwood 1978). These relationships have been also observed in laboratory materials in which the magma flow was simulated (Wing-Fatt \& Stacey 1966, Dragoni et al. 1997).

\section{APPLICATIONS}

The method of anisotropy of magnetic susceptibility can be applied in various volcanic formations: dykes and sills, lava flows, pyroclastic flows, ignimbrites.

\subsection{Dykes and sills}

Dykes are primary conduits of magma formed in the mantle and emplaced into the crust by filling fractures created during an extensional stress regime. It is clear that the magma migrates upwards, however, the flow path may include lateral transport to great distances from the source. AMS data from chilled margins of dykes and other sheet-like intrusions can potentially yield the flow plane, the flow direction and even the flow sense (Knight \& Walker 1988). Determining magmatransport directions in dykes and/or sills is one of the most important steps forward in our understanding of magmatic plumbing systems. There are several case studies exhibiting this application (Rochette et al. 1991, Archanjo et al. 2000, Herrero-Berrera et al. 2001, Gil et al. 2002, among others).

Standard sampling of dykes involves collection of samples from within $10 \mathrm{~cm}$ of the two chilled margins - minimum of six samples per each margin - because often the middle of the dyke has little to do with the direction of the flow (Staudigel et al. 1992, Tauxe et al. 1998). This applies especially in cases of dykes thicker than $1.5 \mathrm{~m}$, where the primary flow fabric is much more easily lost because the inner part of the structure is characterized by: (1) slower and less regular flow, resulting in poorly defined fabric, and (2) larger heat capacity, causing the magma to remain fluid for some time inside the already chilled margins. The basic principles of AMS interpretation of flow directions in dykes are shown in Figure 2 . In the ideal case, the $K_{1}$ directions from the two margins are distinct and fall on either side of the dyke trace. The fact that the western margin data plot on the western side and the eastern margin data plot on the eastern side suggests that the flow was upwards.

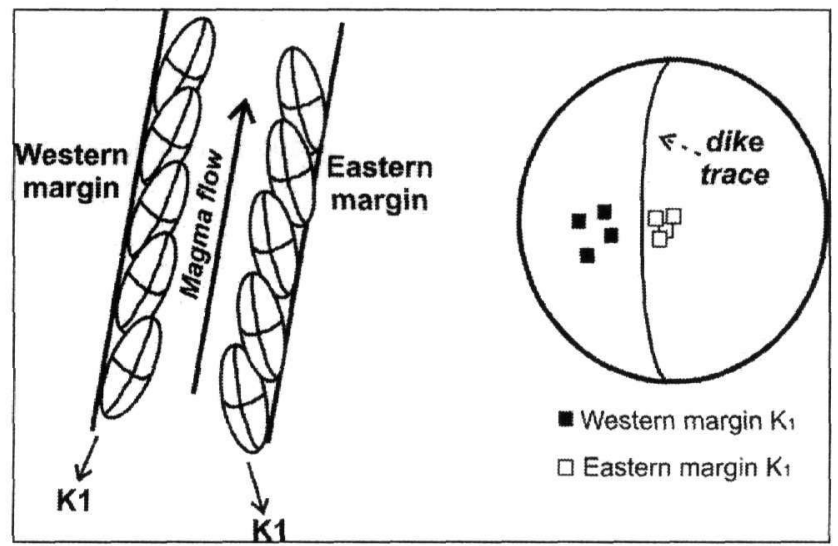

Figure 2. Principles of AMS for interpretation of flow directions in dykes (After Knight \& Walker 1988, Tauxe 1998).

The orientation of the magnetic foliation can also be used to distinguish between different structures, e.g. sills and dykes, a task sometimes impossible simply by field observations (Halvorsen 1974). In the case of sills the foliation planes are almost horizontal and similar to each other, while throughout a dyke swarm the foliation planes are distributed along various semi-vertical directions. 


\subsection{Lava flows}

The application of the anisotropy of magnetic susceptibility technique in lava flows is more complicated than in dykes/sills because of two aspects. Firstly, the flow direction is less wellconstrained since the magma flows in an open environment, and secondly, there are no imbricated margins to provide directional information.

Generally, in lava flows a planar fabric with sub-horizontal $\mathrm{K}_{1}, \mathrm{~K}_{2}$ axes is observed. However, flow planes and directions can be widely dispersed throughout the lava flow due to local flow conditions. A typical example can be seen in Figure 3. This Quaternary lava flow of basaltic type can be clearly followed from the volcano to its toe. Where the flow was faster and possibly less viscous the fabrics are well defined (Fig. 3a), whereas fabrics near the nose of the flow are poorly defined (Fig. 3 b) due to more irregular flow or less alignment because of the slower speed and greater viscosity.

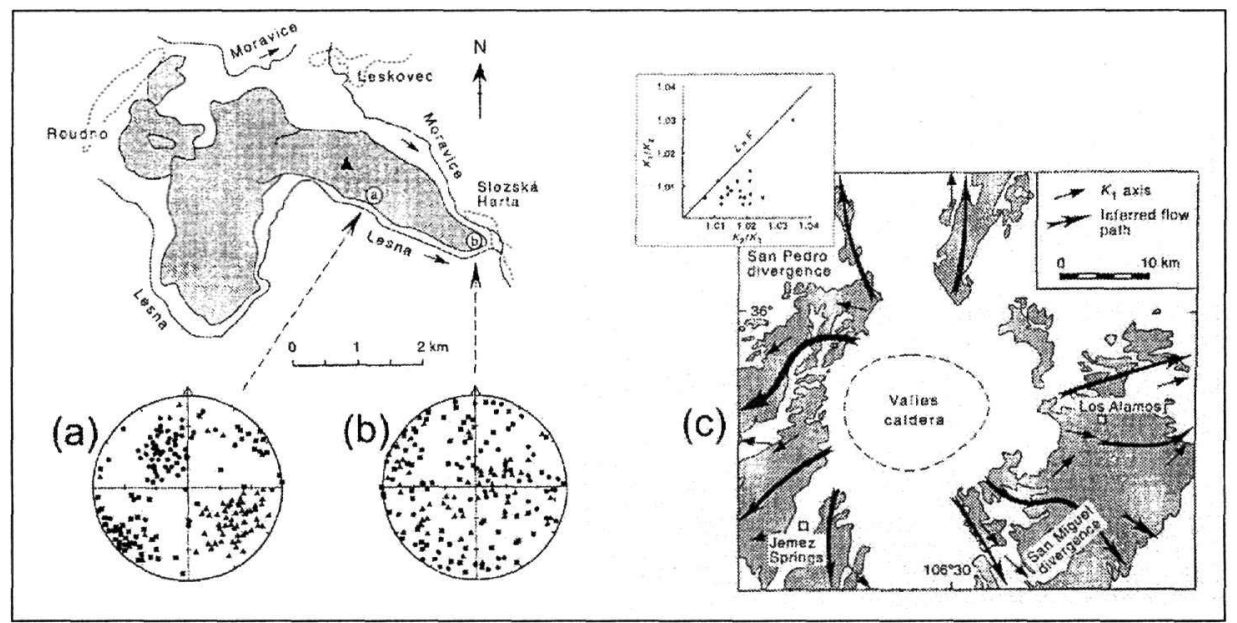

Figure 3. Magnetic fabrics and flow directions from (a) \& (b) The Chribsky Les lava flow, Moravia, Czechoslovakia (After Kolofikova 1976), (c) The Tshirege member of the upper Bandelier Tuff, Valles Caldera, New Mexico (After MacDonald \& Palmer 1990).

Magnetic fabrics, apart from defining local flow conditions, can also be applied to determine the magma source of the lava flow. The flow path is inferred by the directions of maximum susceptibility axes, $\mathrm{K}_{1}$, which are pointing away from the volcanic centre. This approach is demonstrated in an example of MacDonald \& Palmer 1990; magnetic fabrics helped to determine the sources of flows where these were uncertain (Fig. 3c). If AMS is applied on Miocene or younger occurrences, by indicating the direction in which the magma source is located, it can help to assess the present-day volcanic hazards.

A noteworthy factor that must be taken into account when interpreting AMS data is the eruption environment of the flow. It has been suggested that the magnetic fabrics of subaerial lavas differ from those of subaquous flows (Ellwood \& Fisk 1977, Ellwood 1978). The former commonly have a consistent fabric, while the latter are said to have more random fabrics (Ellwood 1978). This difference may result from faster cooling rates, several chemical changes, and degassing phenomena caused by the presence of water during deep-sea eruptions.

\subsection{Pyroclastic flows}

The behaviour of pyroclastic rocks is more complicated, since deposition of the pyroclastic material and cooling may partially overlap. Moreover, the transportation and deposition can be highly variable ranging from concentrated and laminar flows to turbulent currents. However, many studies showed that pyroclastic flows have the ability to preserve in their fabric imprints of the flow direction during their emplacement, as well as information on the vent position (Knight et al. 1986, Hillhouse \& Wells 1991, Seaman et al. 1991, MacDonald et al. 1992, Cagnoli \& Tarling 1997). 
The anisotropy of magnetic susceptibility depends on the anisotropy of each mineral grain and the spatial distribution of the grains within the rock. Thus, it is a powerful indicator of the preferred orientation of minerals and provides information about the processes leading to the transport and deposition of pyroclastic rocks. This approach was used by Zanella et al. (1999), io study the emplacement dynamics of pyroclastic surge deposits from Vulcano (Aeolian Islands, Italy). The foliation planes were horizontal and well-defined, while in most sites the lineations were directed upflow towards the eruptive centre of the La Fossa caldera.

\subsection{Ignimbrites}

Studying the magnetic fabric of ignimbrites with known source areas, Ellwood (1982) illustrated the potential use of the anisotropy of magnetic susceptibility in these rocks in order to locate their sources. More recently the use of the AMS technique has been extended in undeformed ignimbrites, as a flow fabric delineator (Seaman et al. 1991, Lamarche \& Froggatt 1993, Palmer et al. 1996, Palmer \& MacDonald 1999). In a recent study by Wang et al. (2001) the magnetic anisotropy has been also used in order to check whether some stratigraphically and geochemically similar units originated from the same source.

\section{AMS DATA FROM GREECE}

The AMS technique has been applied in various volcanic formations of continental Greece and Southern Aegean: Almopia, Elatia, Gavra, Kos, Samothraki and Samos. Preliminary results of the above studies, together with existing published data from Greek volcanic rocks (Fig. 4) are presented here (Table 1).

Table 1. Existing AMS data from Greek volcanics (1: Morris 2000, 2: Atzemoglou et al. 2001, 3: ongoing research; 4: Morris, personal communication; 5: Kondopoulou et al. 2004, 6: Zananiri 2000).

\begin{tabular}{lrlrrrr}
\hline Location & \multicolumn{1}{c}{ Age } & Lithology & Sites & $\mathbf{K}_{\mathrm{m}}\left(\times \mathbf{1 \mathbf { 1 0 } ^ { - 3 }} \mathbf{S I}\right)$ & $\mathbf{P}^{\prime}$ & T/shape \\
\hline Aegina $^{(1)}$ & Plio-Quaternary & Lava flow & 13 & 19.9 & 1.080 & oblate \\
Almopia $^{(2)}$ & Plio-Quaternary & Lava flow & 6 & 14.2 & 1.028 & 0.254 \\
Kos $^{(3)}$ & Plio-Miocene & Lava flow & 5 & 4.6 & 1.089 & 0.314 \\
Patmos $^{(4)}$ & Plio-Miocene & Lava flow & 5 & 0.9 & 1.033 & oblate \\
Samothraki $^{(5)}$ & Early Miocene & Lava flow & 4 & 14.8 & 1.043 & 0.246 \\
Samos $^{\left({ }^{(3)}\right.}$ & Miocene & Lava flow & 3 & 8.3 & 1.023 & 0.364 \\
Elatia $^{(6)}$ & Mid-Oligocene & Lava flow & 8 & 29.3 & 1.027 & 0.068 \\
Gavra $^{(6)}$ & Late Oligocene & Lava flow & 2 & 0.3 & 1.045 & 0.376 \\
\hline
\end{tabular}

* Oblate ellipsoid: $T>0$, Prolate ellipsoid: $T<0$. The shape of the AMS ellipsoid is indicated where no mean value for $\mathrm{T}$ parameter was available.

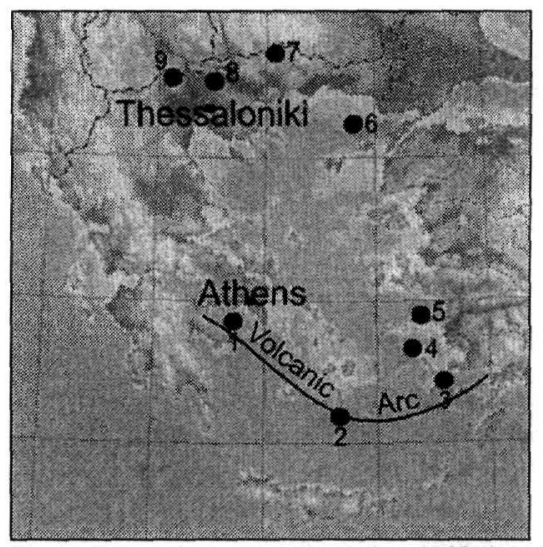

Figure 4. Location map of existing AMS data in Greece (1: Aegina, 2: Santorini, 3: Kos, 4: Patmos, 5: Samos, 6: Samothraki, 7: Elatia, 8: Gavra, 9: Almopia). 
In the majority of cases the magnetic fabric is well-defined with prevailing oblate ellipsoids (Fig. 5). $K_{3}$ axes, which are perpendicular to the magnetic foliation, range from vertical to semi-vertical, defining thus a sub-horizontal flow plane. $K_{1}$ and $K_{2}$ axes are either grouped, in semi-horizontal positions, or moving along the flow plane. The anisotropy degree is low, as expected for volcanic rocks, ranging from 3 to $8 \%$, while the magnetic susceptibility is of the order of $10^{-3}$. Representative plots of the magnetic fabric are shown in Figure 6.

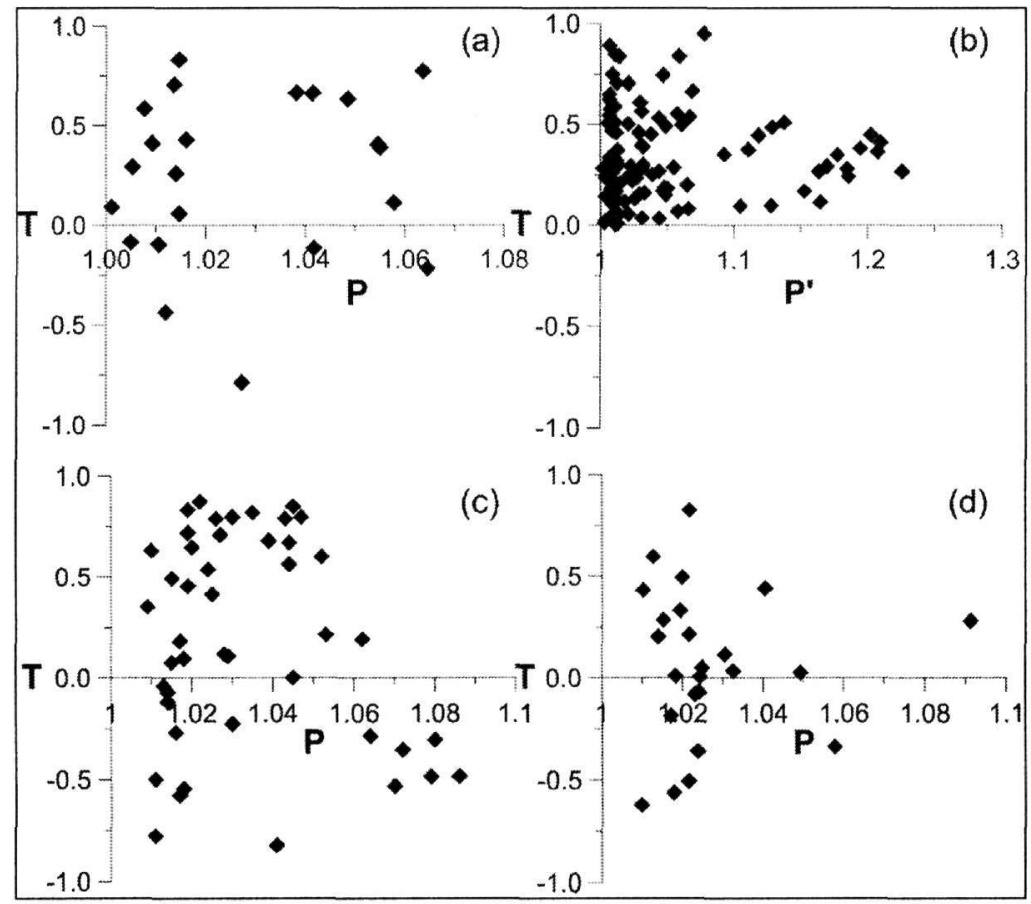

Figure 5. Pvs. T plot for various Greek volcanics: (a) Almopia, (b) Kos-Samos, (c) Samothraki, (d) Elatia. Oblate susceptibility ellipsoids fall in the $T>0$ domain, while prolate susceptibility ellipsoids are in the $T<0$ domain. For definitions of parameters see text.

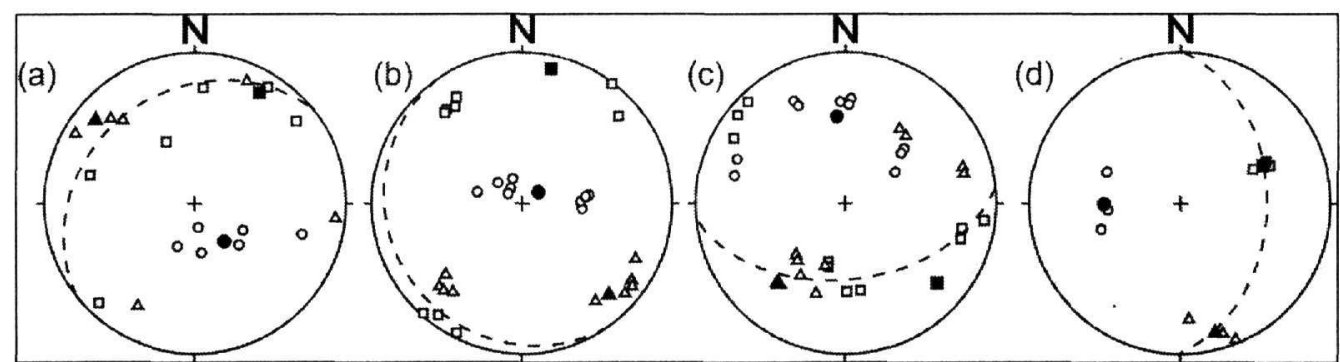

Figure 6. Lower hemisphere stereographic projections of AMS data (direction of axes of the AMS ellipsoid) from several sites from Greek volcanics: (a) Almopia, (b) Kos, (c) Samothraki, (d) Elatia. Squares represent $K_{1}$ axes, triangles $\mathrm{K}_{2}$ axes, circles $\mathrm{K}_{3}$ axes (open symbols are sample values and filled symbols are site means). Dashed lines represent foliation $=$ flow planes, perpendicular to $\mathrm{K}_{3}$ axis.

\section{CONCLUSIONS}

The method of the anisotropy of magnetic susceptibility (AMS) can be successfully applied to a variety of volcanic formations allowing us to reach meaningful conclusions about their emplacement mechanism and flow direction. Thus, numerous studies have been carried out worldwide in dykes 
and sills, lava flows, pyroclastic flows and ignimbrites. Recently, the method has been used in petrofabric studies of Greek volcanic rocks. Published and new data from Aegina, Almopia, Elatia, Gavra, Kos, Patmos, Samos, Samothraki and Santorini are presented. In the majority of cases the magnetic fabric was well-defined, with low anisotropy degree and quite high susceptibility values. The shape of the AMS ellipsoid was predominantly oblate.

\section{ACKNOWLEDGEMENTS}

Professor R. Lanza and Dr. A. Morris are warmly thanked for fruitful discussions, which helped to clarify several aspects of the AMS technique in volcanic rocks. This is a Geophysical Laboratory of the Aristotle University of Thessaloniki contribution number \#643/2004.

\section{REFERENCES}

Archanjo, C.J., Trindade, R.I., Macedo, J.W.P., and Araujo, M.G., 2000. Magnetic fabric of a basaltic dyke swarm associated with Mesozoic rifting in northeastern Brazil, J. South Am. Earth Sci., 13, 179-189.

Atzemoglou, A., Kondopoulou, D., and I. Zananiri, 2001. Paleomagnetism and magnetic fabrics of the Almopias, Thessaly and Milos volcanics. Implications for the regional deformation, Bulletin of the Geological Society of Greece, Vol. XXXIV/1, 61-68.

Bolshakov, A.S., and Skorodkin, Y.P., 1967. Magnetic anisotropy of eruptive rocks, Akad. Nauk. SSSR Izv. Fiz. ZemIli, 1967, 78-82.

Cagnoli, B., and Tarling, D.H., 1997. The reliability of anisotropy of magnetic susceptibility (AMS) data as flow direction indicators in friable base surge and ignimbrite deposits: Italian examples, J. Volcanol. Geotherm. Res., 75, 309-320.

Canon-Tapia, E. and Pinkerton, H., 2000. The anisotropy of magnetic susceptibility of lava flows: an experimental approach, J. Volcanol. Geotherm. Res., 98, 219-233.

Dragoni, M., Lanza, R., and Tallarico, A., 1997. Magnetic anisotropy produced by magma flow: theoretical model and experimental data from Ferrar dolerite sills (Antarctica), Geophys.J. Int., 128, 230-240.

Ellwood, B.B., 1978. Flow and emplacement direction determined for selected basaltic bodies using magnetic susceptibility anisotropy measurements, Earth Planet. Sci. Lett., 41, 254-264.

Ellwood, B.B., and Fisk, M.R., 1977. Anisotropy of magnetic susceptibility variations in a single Icelandic columnar basalt, Earth Planet. Sci. Lett., 35, 116-122.

Ellwood, B.B., 1982. Estimates of flow direction for calc-alkaline welded tuffs and paleomagnetic data reliability from anisotropy of magnetic susceptibility measurements: central San juan Mountains, southwest Colorado, Earth Planet. Sci. Lett., 59, 303-314.

Ernst, R.E., 1990. Magma flow directions in two mafic Proterozoic dyke swarms of the Canadian shield, as estimated using anisotropy of magnetic susceptibility data. In: Parker, A.J., Rickwood, P.C, Tucker, D.H. (Eds.), Mafic Dykes and Emplacement Mechanisms, Balkema, Rotterdam, pp. 231-235.

Gil, A., Lago, M., Gale, C., Pocovi, A., and Arranz, E., 2002. Magnetic fabric in folded sills and lava flows. A case study in the Permian basalts of the Anayet Massif (Pyrenean Axial Zone, Spain), Tectonophysics, 350, $1-15$.

Halvorsen, E., 1974. The magnetic fabric of some dolerite intrusions, NE Spitsbergen: Implications for their mode of emplacement, Earth Planet. Sci. Lett., 21, 127-133.

Herrero-Bervera, E., Walker, G.P.L., Canon-Tapia, E., and Garcia, M.O., 2001. Magnetic fabric and inferred flow direction of dikes, conesheets and sill swarms, Isle of Skye, Scotland, J. Volcanol. Geotherm. Res., 106, 195-210.

Hillhouse, J.W., and Wells, R.E., 1991. Magnetic fabric, flow directions, and source area of the lower Miocene Peach Springs Tuff in Arizona, California and Nevada, J. Geophys. Res., 96, 12443-12460.

Jelinek, V., 1981. Characterization of the magnetic fabric of rocks, Tectonophysics, 79, T63-T67.

Khan, M.A., 1962. The anisotropy of magnetic susceptibility of some igneous and metamorphic rocks, J. Geophys. Res., 67, 2867-2875.

Knight, M.D., and Walker, G.P.L., 1988. Magma flow direction in dikes of the Koolau complex, Oahu, determined from magnetic fabric studies, J. Geophys. Res., 93, 4301-4319.

Knight, M.D., Walker, G.P.L., Ellwood, B.B., and Diehl, J.F., 1986. Stratigrapfy, paleomagnetism, and magnetic fabric of the Toba tuffs: constraints on the sources and eruptive style, J. Volcanol. Geotherm. Res., 56, 205220.

Kolofikova, O., 1976. Geological interpretation of measurements of magnetic properties of basalts on example of the Chribsky Las Lava Flow of the Velky Roudny Volcano (Nizky Jesenik), Cas. Mineral. Geol., 21, 387396 (In Czech). 
Kondopoulou, D., Michard, A., Zananiri, I., Feinberg, H., Atzemoglou, A., Pozzi, J.-P., and Voidomatis, Ph., 2004. Neogene tectonic rotations in the vicinity of the North Aegean Trough: new paleomagnetic evidence from Athos and Samothraki (Greece). (submitted)

Lamarche, G., and Froggatt, P.C., 1993. New eruptive vents for the Whakamaru ignimbrite (Taupo volcanic sone) identified from magnetic fabric studies, N.Z. J. Geol. Geophys., 36, 213-222.

Le Pennec, J.-L., Chenn, Y., Diot, H., Froger, J.-L., and Gourgaud, A., 1998. Interpretation of anisotropy of magnetic susceptibility fabric of ignimbrites in terms of kinematic and sedimentological mechanisms. An Anatolian case study, Earth Planet. Sci. Lett., 157, 105-127.

MacDonald, W.D., and Palmer, H.C., 1990. Flow directions in ash-flow tuffs: a comparison of geological and magnetic susceptibility measurements, Tshirege member (upper Bandelier Tuff) Valles Caldera, New Mexico, USA, Bull. Volcanol., 53, 45-59.

MacDonald, W.D., Palmer, H.C., and Hayatsu, A., 1992. Egan Range Volcanic Complex, Nevada: geochronology, paleomagnetism and magnetic fabric, Phys. Earth Planet. Inter., 74, 109-126.

McKenzie, D., McKenzie, J.M., and Saunders, R.S., 1992. Dike emplacement on Venus and Earth, J. Geophys. Res., 97, 15990-15997.

Morris, A., 2000. Magnetic fabric and palaeomagnetic analyses of the Plio-Quaternary calc-alkaline series of Aegina Island, South Aegean volcanic arc, Greece, Earth Planet. Sci. Lett., 176, 91-105.

Palmer, H.C., McDonald, W.D., Gromme, C.S., and Ellwood, B.B., 1996. Magnetic properties and emplacement of the Bishop Tuff, California, Bull. Volcanol., 58, 101-116.

Palmer, H.C., and MacDonald, W.D., 1999. Anisotropy of magnetic susceptibility in relation to source vents of ignimbrites: empirical observations, Tectonophysics, 307, 207-218.

Raposo, M.I.B., and D'Agrella-Filho, M.S., 2000. Magnetic fabrics of dike swarms from SE Bahia State, Brazil: their significance and implications for Mesoproterozoic basic magmatism in the Sao Francisco Craton, Precambrian Res., 99, 309-325.

Rochette, P., Jenatton, L., Dupuy, C., Boudier, F., and Reuber, I., 1991. Diabase dikes emplacement in the Oman ophiolite: a magnetic fabric study with reference to geochemistry. In: Peters, Tj., Nicolas, A., Coleman, R.G. (Eds.), Ophiolite Genesis and Evolution of the Oceanic Lithosphere, Kluwer, Dordrecht, pp. 5582.

Seaman, S.J., Mclntosh, W.C., Geissman, J.W., Williams, M.L., and Elston, W.E., 1991. Magnetic fabrics of the Bloodgood Canyon and Shelley Peak Tuffs, southwestern New Mexico: implications for emplacement and ateration processes, Bull. Volcanol., 53, 460-476

Smith, J.V., 1998. Interpretation of domainal groundmass textures in basalt lavas of the southern Lamington Volcanics, eastern Australia, J. Geophys. Res., 103, 27383-27391.

Staudigel, H., Gee, J., Tauxe, L., and Varga, R.J., 1992. Shallow intrusive directions of sheeted dikes in the Troodos ophiolite: anisotropy of magnetic susceptibility and structural data, Geology, 20, 841-844.

Tarling, D.H., and Hrouda, F., 1993. The magnetic anisotropy of rocks, Chapman and Hall, London, 217 pp.

Tauxe, L., Gee, J.S., and Staudigel, H., 1998. Flow directions in dikes from anisotropy of magnetic susceptibility data: the bootstrap way, J. Geophys. Res., 103, 17775-17790.

Tauxe, L., 1998. Paleomagnetic principles and practice, Kluwer Academic Publishers, Dordreht/Boston/London, pp. 299.

Varga, J.V., Gee, J.S., Staudigel, H., and Tauxe, L., 1998. Dike surface lineations as magma flow indicators within the sheeted dike complex of the Troodos ophiolite, Cyprus, J. Geophys. Res., 103, 5241-5256.

Wang, X., Roberts, J., and Schmidt, P., 2001. Flow directions of Carboniferous ignimbrites, southern New England Orogen, Australia, using anisotropy of magnetic susceptibility, J. Volcanol. Geotherm. Res., 110, 1-25.

Wing-Fatt, L., and Stacey, F.D., 1966. Magnetic anisotropy of laboratory materials in which magma flow is simulated, Pure Appl. Geophys., 64, 78-80.

Zananiri, I., 2000. Examination of the relationships between magnetic and mineralogical - histological anisotropy in granitic rocks, Master Thesis, Department of Geophysics, School of Geology, Aristotle University of Thessaloniki, Greece.

Zanella, E., De Astis, G., Dellino, P., Lanza, R., and La Volpe, L., 1999. Magnetic fabric and remanent magnetization of pyroclastic surge deposits from Vulcano (Aeolian Islands, Italy), J. Volcanol. Geothern. Res., 93, 217-236. 